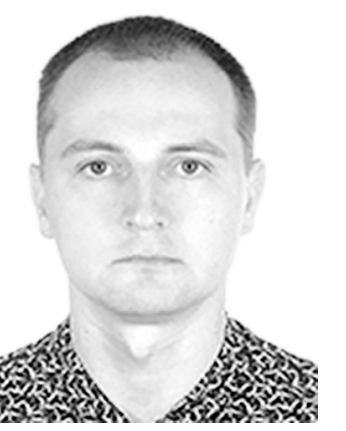

\title{
ДЕРЖАВНИЙ КОНТРОЛЬ ЗА ОБІГОМ ЦИВІЛЬНОЇ ВОГНЕПАЛЬНОї ЗБРОЇ В УKPAÏHI
}

\author{
ПРИПУТЕНЬ Дмитро Сергійович - доктор юридичних наук, доценТ, \\ професор кафедри загальноправових дисциплін Дніпропетровського державного \\ університету внутрішніх справ
}

DOI 10.32782/LAW.UA.2020.3.7

Зараз на розгляді у комітеті Верховної Ради України перебуває проєкт Закону України «Про обіг ицвільної вогнепальної зброї та бойових припасів до неї». Наукова стаття присвячена актуальній для Украӥни темі державного контролю за обігом иивільної вогнепальної зброї. Такий державний контроль необхідний задля безпеки всіх громадян України, оскільки збільшення кількості осіб, які будуть власниками иивільної вогнепальної зброї, збільшує ризик неправомірного ій застосування. 3 іншого боку, прийняття законодавчого акта забезпечить можливість реалізачї державними органами заходів, спрямованих на дотримання норм права власниками иивільної вогнепальної зброї.

у роботі державний контроль розглядається як одна із фуункиій державного управління, сутність якої полягає у перевіриі діяльності підконтрольних суб'єктів на відповідність законодавчим нормам. Враховуючи це та зміст понять «иивільна вогнепальна зброя» та «обіг зброї», визначений проєктом, ми сбормулювали власне визначення «державний контроль за обігом ицвільної вогнепальної зброї».

У статті наголошено, що суб'єктом такого контролю є органи (посадові особи) Наиіональної поліиї України. Тому автором запропоновано внести зміни до Закону Украӥни «Про Начіональну полічію» та до відомчих нормативно-правових актів, визначивши контрольні повноваження поліщейсъких. Також запропоновано прийняти окремий наказ Міністерства внутрішніх справ України
«Про затвердження Положення про здійснення державного контролю за обігом изивільної вогнепальної зброї».

Визначено, що державний контроль за обігом иивільної вогнепальної зброї відбувається у формі перевірок.

З'ясовано, що за порушення правил обігу цивільної вогнепальної зброї винна особа несе кримінальну, адміністративну, дисииплінарну та иииільно-правову відповідальність.

3'ясовано, що законопроєктом на особу, яка застосувала зброю, у випадку заподіяння тілесних ушкоджень покладено обов'язок здійснити виклик екстреної медичної допомоги, вжити заходів до охорони місия подї та негайно повідомити органам Начіональної полічї про випадок застосування зброї. Автор робить висновок, що законодавець не передбачає відповідальності иієї особи за невиконання такого обов'язку.

Тому автором запропоновано доповнити Кодекс України про адміністративні правопорушення новою статтею 190-1 «Неповідомлення про випадок застосування зброї».

Ключові слова: контроль, обіг зброї, ичивільна вогнепальна зброя, поліщія, адміністративна відповідальність.

\section{Актуальність теми}

Актуальність обраної тематики дослідження обгрунтована законодавчими новелами у сфері обігу цивільної вогнепальної зброї, а саме - розробкою, опрацюванням та у подальшому прийняттям з метою запровадження у суспільне життя України 
проєкту Закону України «Про обіг цивільної вогнепальної зброї та бойових припасів до неї» [1]. Поки триває обговорення цього проєкту маємо можливість висловити власну позицію щодо удосконалення окремих його положень, зокрема щодо удосконалення такої важливої процедури, як здійснення державного контролю за обігом цивільної вогнепальної зброї в Україні.

Актуальність обраного напрямку дослідження доводять і статистичні дані. Так, Офіс Генерального Прокурора України офіційно повідомляє, що в січні-червні 2020 року порушено 3519 кримінальних проваджень за статтею 263 Кримінального кодексу України (носіння, зберігання, придбання чи збут вогнепальної зброї (крім гладкоствольної мисливської), бойових припасів, вибухових речовин/пристроїв без передбаченого законом дозволу [2]). Крім того, 331 кримінальне правопорушення було кваліфіковано як теракт, а у 296 випадках самостійне кримінальне правопорушення супроводжувалось ще й використанням зброї та боєприпасів [3]. Тобто кількість зазначених правопорушень за шість місяців поточного року підтверджує необхідність залучення додаткових сил та засобів для вирішення проблеми незаконного обігу цивільної вогнепальної зброї в Україні.

\section{Постановка проблеми}

Ця наукова стаття присвячена саме державному контролю за обігом цивільної вогнепальної зброї, хоча їі легалізація також видається достатньо дискусійним питанням. Зазначений нами вид державного контролю необхідний задля безпеки всіх громадян України, оскільки збільшення кількості осіб, які будуть власниками цивільної вогнепальної зброї, збільшує ризик неправомірного їі застосування. 3 іншого боку прийняття законодавчого акту забезпечить можливість реалізації державними органами заходів, спрямованих на дотримання норм права власниками цивільної вогнепальної зброї.

Також слід наголосити, що одним із задекларованих кроків Стратегії розвитку системи Міністерства внутрішніх справ України до 2020 року є саме удосконалення законодавчих механізмів регулювання i контролю за обігом і використанням зброї та вибухонебезпечних речовин [4]. I саме на органи Міністерства внутрішніх справ України та Національної поліції покладається обов'язок здійснення державного контролю за обігом вказаного виду зброї відповідно до аналізованого нами проєкту [1].

Аналіз публікацій, у яких започатковано розв'язання цієї проблеми

Питання застосування зброї в Україні завжди були предметом досліджень багатьох учених-адміністративістів. Зокрема, питання застосування поліцейськими вогнепальної зброї вивчали такі вітчизняні науковці, як П.П.Андрушко, О. М. Бандурка, Ю.В. Баулін, В.П. Віденко, М. І. Еропкін, М.Е. Ефімов, А.Т. Комзюк, А.В. Корінець, Н.Т. Куц, В.Д.Поливанюк, А.А. Попов, А.О. Терещук, І.С. Тишкевич, М.П. Федоров, О.С. Фролов, А.Г. Чистоклетов та інші.

Окремі питання застосування вогнепальної зброї досліджувалися і зарубіжними вченими (Б. Перроу та Б. Фаррелл, (В. Perrou \& B. Farrell), Е. Дж. Пініцотто (А. J. Pinizzotto), I. М. Уразалін, М. Ш. Шайдуллін та іншими).

Крім того, теоретичні засади сутності та змісту державного контролю, а також його відмінності від нагляду в контексті державного управління вивчали такі науковці, як В.Б. Авер'янов, О.Ф. Андрійко, Д.М. Бахpax, В.М. Гаращук, І.П. Голосніченко, Є.В. Додін, С.В. Ківалов, Р.А. Калюжний, А.В. Коваль, В.В. Копєйчиков, А.Т. Кривенко, Є.Б. Кубко, В.Ф. Опришко, Ю.С. Шемшученко, Х.П. Ярмакі та інші.

3 урахуванням того, що тема статті висвітлює положення законопроєкту 2020 року, то подібного наукового доробку в українській науці не було.

Мета написання даної наукової статті - з'ясувати особливості здійснення державного контролю за обігом цивільної вогнепальної зброї в Україні та надати пропозиції щодо його удосконалення.

\section{Виклад основного матеріалу}

3 метою встановлення сутності державного контролю за обігом цивільної вогнепальної зброї пропонуємо з'ясувати зміст означеного нами поняття. 


\section{Адміністративне право}

Звертаючись до тлумачних словників української мови, можна побачити закономірність вираження змісту поняття «контроль» через перевірку, облік діяльності кого-небудь, чого-небудь, нагляд за кимось, чимось [5]. Тобто контроль виражається у формі таких дій, як перевірка, а також відбувається ототожнення таких понять, як «контроль» та «нагляд». Проте наукові погляди не такі однозначні у цьому питанні, а дискусії з приводу тотожності та змінності контролю та нагляду відбуваються і дотепер.

Не вступаючи у детальну наукову дискусію з приводу теоретичного змісту таких понять, як «контроль», «державний контроль», висловлено власне ставлення до даного явища у контексті досліджуваного питання. Наша позиція у цій науковій роботі полягає у тому, що контроль є невід'ємною частиною державного управління, тому нами державний контроль розглядається як одна із функцій державного управління. Сутність державного контролю в такому випадку полягає в аналізі діяльності підконтрольних суб'єктів на відповідність законодавчим нормам.

Державним контроль вважається тому, що здійснюється державними органами. У нашому випадку суб'єктами державного контролю $є$ уповноважені органи (посадові особи) Національної поліції України. Позиція щодо визначення суб'єктів державного контролю за обігом цивільної вогнепальної зброї конкретно висловлена у статті 44 проєкту Закону України «Про обіг цивільної вогнепальної зброї та бойових припасів до неї» [1].

Крім того, у статті 1 проєкту [1] чітко визначені такі поняття, як «обіг зброї» та «цивільна вогнепальна зброя», що надає конкретне уявлення про обсяг контрольних повноважень поліцейських у даному питанні.

Узагальнюючи викладене, під державним контролем за обігом цивільної вогнепальної зброї пропонуємо розуміти діяльність уповноважених на те органів (посадових осіб) Національної поліції України щодо перевірки дотримання норм законодавства України фізичними та юридичними особами під час виробництва, продажу, обміну, дарування, передачі, придбання, колекці- онування, експонування, спадкування, обліку, зберігання, носіння, транспортування, транзиту, застосування, вилучення, утилізації вогнепальної зброї та бойових припасів, які не заборонені законом для цивільного обігу, які можуть перебувати у власності фізичних осіб та юридичних осіб у порядку, визначеному законом. Дане визначення i пропонуємо закріпити на законодавчому рівні, доповнивши ним статтю 1 проєкту Закону України «Про обіг цивільної вогнепальної зброї та бойових припасів до неї».

3 викладеного вище вбачається, що в структурі Національної поліції України має бути спеціально уповноважений орган (посадова особа), який здійснює такий вид контролю. На наш погляд, цілком очевидним 6 те, що такими посадовцями мають бути поліцейські дозвільної системи, оскільки цивільна вогнепальна зброя цілком логічно має стати об'єктом дозвільної системи. Саме тому відповідний обсяг додаткових повноважень слід покласти на таких осіб, закріпивши їх зміст на загальнодержавному та відомчому рівнях.

Аналіз проєктів Законів України «Про обіг цивільної вогнепальної зброї та бойових припасів до неї» (реєстр. № 4335) [1] та «Про внесення змін до Кодексу України про адміністративні правопорушення та Кримінального кодексу України для реалізації положень Закону України «Про обіг цивільної вогнепальної зброї та бойових припасів до неї» (реєстр. № 4336) [6] дозволяє зробити висновок про відсутність внесення змін до Закону України «Про Національну поліцію» у зв'язку із прийняттям вказаних проєктів.

Та ми все ж пропонуємо відобразити згадані вище акценти щодо повноважень поліцейських на законодавчому рівні і внести зміни до пункту 21 статті 23 Закону України «Про Національну поліцію» [7], виклавши його у такій редакції: «Здійснює контроль за дотриманням фізичними та юридичними особами спеціальних правил та порядку зберігання і використання цивільної вогнепальної зброї та боєприпасів до неї, спеціальних засобів індивідуального захисту та активної оборони, вибухових речовин і матеріалів... » (далі по тексту). Також у пункті 
22 цієї статті [7] пропонуємо перед словом «вогнепальної» додати слово «цивільної».

Крім того, на нашу думку, потребує редагування стаття 46 Закону України «Про Національну поліцію» [7]. Враховуючи збільшення кількості осіб, яким буде надано право володіння та застосування цивільної вогнепальної зброї в Україні, вважаємо, що можна спрогнозувати збільшення кількості правопорушень, пов'язаних із іiі неправомірним застосуванням. Вирішувати конфліктні ситуації на місця події, а також припиняти та документувати такі правопорушення будуть поліцейські, повноваження яких залишаються незмінними у випадку прийняття поточної редакції законопроєктів. 3 метою забезпечення особистої безпеки поліцейських та безпеки громадян України пропонуємо розширити повноваження поліцейських у частині застосування ними вогнепальної зброї до правопорушників, які тримають у руках зброю. Зміст та редакція таких змін потребують додаткового вивчення та наукового опрацювання, а можливо і громадського обговорення.

Прийняття законопроєктів також спонукає до визначення повноважень поліцейських і на відомчому рівні. На наш погляд, відповідні зміни мають відбутися в чинних нормативно-правових актах Міністерства внутрішніх справ України та Національної поліції Україні у сфері дозвільної системи. Також вважаємо доречним прийняття окремого наказу Міністерства внутрішніх справ України «Про затвердження Положення про здійснення державного контролю за обігом цивільної вогнепальної зброї», який би чітко визначав суб'єктів, об’єктів такого контролю, строки, порядок контрольних дій, документування результатів контрольних перевірок, бланки документації тощо. Запропонований нами нормативно-правовий акт був би керівною інструкцією для поліцейських у частині проведення контрольних перевірок власників цивільної вогнепальної зброї, а також у частині подальших дій поліцейських за результатами таких перевірок.

Враховуючи викладене, можна сказати, що державний контроль за обігом цивільної вогнепальної зброї здійснюється у фор- мі перевірки (дотримання умов зберігання цивільної вогнепальної зброї та бойових припасів до неї, ведення обліку цивільної вогнепальної зброї, транспортування цивільної вогнепальної зброї, тощо). Водночас державним контролем вважається і оформлення результатів таких перевірок, наприклад, припис про усунення виявлених порушень; припинення дії Посвідчення власника зброї; притягнення до відповідальності за порушення правил обігу цивільної вогнепальної зброї.

Що стосується відповідальності за порушення правил обігу цивільної вогнепальної зброї, то відповідно до законопроєкту № 4335 [1] винна особа несе кримінальну, адміністративну, дисциплінарну та цивільно-правову відповідальність. Зупинимося на деяких аспектах адміністративної відповідальності, які, на наш погляд, потребують удосконалення.

Проведений нами аналіз законопроєктів дозволяє зробити висновок, що, зобов'язуючи особу, яка застосувала зброю, здійснити виклик екстреної медичної допомоги, вжити заходів до охорони місця події та негайно повідомити органам Національної поліції про випадок застосування зброї у випадку заподіяння тілесних ушкоджень [1], законодавець не передбачає відповідальності цієї особи за невиконання такого обов'язку.

Саме тому вбачаємо за доцільне запропонувати доповнити Кодекс України про адміністративні правопорушення [8] новою статтею 190-1 «Неповідомлення про випадок застосування зброї».

Диспозицію частини першої даної статті пропануємо викласти у такій редакції: «Неповідомлення екстреної медичної допомоги про випадок застосування зброї власником цивільної вогнепальної зброї у випадку заподіяння тілесних ушкоджень».

Диспозицію частини другої - у такій редакції: «Неповідомлення органам Національної поліції України про випадок застосування зброї власником цивільної вогнепальної зброї у випадку заподіяння тілесних ушкоджень».

Диспозицію частини третьої - у такій редакції: «Ті самі дії, вчинені особою, яку про- 


\section{Адміністративне право}

тягом року було піддано адміністративному стягненню за порушення, передбачене частиною першою або другою цієї статті».

3 викладеного стає зрозумілим, що об'єктом запропонованого складу адміністративного проступку виступають суспільні відносини у сфері обігу цивільної вогнепальної зброї. Об'єктивна сторона, у свою чергу, полягає у бездіяльності, а саме - неповідомленні екстреної медичної допомоги або Національної поліції України про випадок застосування зброї. Важливим акцентом E те, що у ці служби слід повідомляти лише у випадку завдання тілесних ушкоджень людині.

Суб'єктом цього адміністративного правопорушення пропонуємо визнати власника цивільної вогнепальної зброї. Суб'єктивна сторона у цьому випадку проявляється у формі як прямого, так непрямого умислу.

Повноваження щодо складання протоколу за вказане адміністративне правопорушення пропонуємо покласти на уповноважених осіб Національної поліції України, відповідним чином відредагувавши статтю 255 Кодексу України про адміністративне правопорушення [8]. Повноваження щодо вирішення справи по суті пропонуємо покласти на суди загальної юрисдикції, про що слід зазначити у статті 221 Кодексу України про адміністративні правопорушення [8].

Запропоновані нами зміни до законодавства мають бути запроваджені відредагованим проєктом Закону України «Про внесення змін до Кодексу України про адміністративні правопорушення та Кримінального кодексу України для реалізації положень Закону України «Про обіг цивільної вогнепальної зброї та бойових припасів до неї» № 4336 [6] у разі його прийняття.

\section{Висновок}

Підводячи підсумок вище сказаному, вважаємо за необхідне наголосити на тому, що запропоновані для обговорення законопроєкти № 4335 та 4336 потребують додаткового опрацювання, зокрема і в частині реалізації контрольних повноважень поліцейськими у сфері обігу цивільної вогнепальної зброї. Такі повноваження слід додатково продублювати як у Законі України «Про
Національну поліцію», так і у відомчих нормативно-правових актах. Чітке визначення процедури здійснення поліцейськими державного контролю за обігом цивільної вогнепальної зброї пропонуємо закріпити в окремому наказі МВС України для успішної реалізації поліцейськими контрольних повноважень в означеній сфері.

\section{Аітература}

1. Про обіг цивільної вогнепальної зброї та бойових припасів до неї: проєкт Закону України № 4335 від 06.11.2020. URL: $\quad$ http://w1.c1.rada.gov.ua/pls/zweb2/ webproc4 1?pf3511=70363

2. Кримінальний кодекс України від 05.04.2001. URL: https://zakon.rada.gov.ua/ laws/show/2341-14\#Text

3. Злочини зі зброєю у I півріччі 2020: українці продовжують вирішувати побутові конфлікти зі зброєю та зберігати вдома гранати. URL: https://censs.org/\%D0\% $97 \%$ D 0\% B B \% D 0\% B E \% D $1 \% 87 \%$ D $0 \%$ B 8\% D0\% B D \% D 0\% B 8-\% D 0\% B 7\% D 1\%96-\% D0 $\%$ B 7\% D 0\% B 1\% D $1 \% 80 \%$ D 0\% B E \% D $1 \% 94$ $\% \mathrm{D} 1 \% 8 \mathrm{E}-\% \mathrm{D} 0 \% \mathrm{BF} \% \mathrm{D} 1 \% 80 \% \mathrm{D} 0 \% \mathrm{BE} \% \mathrm{D} 1$ $\% 82 \% \mathrm{D} 1 \% 8 \mathrm{~F} \% \mathrm{D} 0 \% \mathrm{~B} 3 \% \mathrm{D} 0 \% \mathrm{BE} \% \mathrm{D} 0 \% \mathrm{BC}-$ $\% \mathrm{D} 1 \% 81 \% \mathrm{D} 1 \% 96 \% \mathrm{D} 1 \% 87 \% \mathrm{D} 0 \% \mathrm{BD} \% \mathrm{D} 1 \% 8 \mathrm{~F}-$ $\% \mathrm{D} 1 \% 87 \% \mathrm{D} 0 \% \mathrm{~B} 5 \% \mathrm{D} 1 \% 80 \% \mathrm{D} 0 \% \mathrm{~B} 2 /$

4. Стратегія розвитку системи Мiністерства внутрішніх справ України до 2020 року. URL: https://mvs.gov.ua/ua/pages/ strategiya_2020.htm

5. Словник української мови: в 11 томах. - Том 4, 1973. - Стор. 271. URL: http:// sum.in.ua/s/kontrolj

6. Про внесення змін до Кодексу України про адміністративні правопорушення та Кримінального кодексу України для реалізації положень Закону України «Про обіг цивільної вогнепальної зброї та бойових припасів до неї»: проєкт Закону України№ 4336 від 06.11.2020. URL: http://w1.c1.rada. gov.ua/pls/zweb2/webproc4 1?pf3511=70364

7. Про Національну поліцію: Закон України від 02.07.2015 № 580-VIII. Урядовий кур'єр від 12.08.2015. № 146.

8. Кодекс України про адміністративні правопорушення від 07.12.1984 року-

№ $\quad 8073-X . \quad$ URL: $\underline{\text { https://zakon.rad/ }}$ show/80731-10a.gov.ua/laws 
Припутень Д.С. - Державний контроль за обігом цивільної вогнепальної зброї...

SUMMARY
A committee of the Verkhowna Rada of Ukraine investigates the project of Law of Ukraine "About traffic of civil fire weapons and ammunition» now The scientific article is devoted to a topical issue. It is state control to traffic of civil fire weapons. This state control is necessary for the safety of all citizens of Ukraine, because magnification of owners of civil fire weapons increases the risk of misuse. On the other hand, the adoption of the legislative act will ensure the possibility for state bodies to implement measures aimed at compliance with the rule of law by owners of civil firear weapons.

In this article, state control is considered as one of the functions of public administration. The essence of this function is to check the activities of controlled subjects for compliance with the law. Given this and the meaning of the terms "civil fire weapons" and "traffic of weapons", defined by the project, we have formulated our own definition of "state control to the traffic of civil fire weapons".

The author underscores that the subject of such control is the bodies (officials) of the National Police of Ukraine. So, the author proposes to project of the Law of Ukraine "On the National Police" and departmental regulations, defining the control powers of police officers. It is also proposed to approve a separate order of the Ministry of Internal Affairs of Ukraine "About approval of the Regulations on state control to the traffic of civil fire weapons".

It is determined that the state control to traffic of civil fire weapons carried out in the form of inspections.

It was found that the guilty person attracted to criminal, administrative, disciplinary or civil liability for violating the rules of traffic of civil fire weapons.

It was found that the person who used weapons and inflicted bodily harm must to call an ambulance and to National Police. And then this person must to guard the scene. The author concludes that the legislator does not establish liability for failure to do this duty.

So, the author proposed to supplement the Code of Ukraine on Administrative Offenses with a new Article 190-1 "Notification of a case of use of weapons.»

Keywords: control, traffic of weapons, civil fire weapon, police, administrative liability. 